\title{
On survival growth and some physiological parameters of Oreochromis niloticus as afftected by dietary ascorbic acid supplementation
}

\author{
Nagat A. Siliem \\ National Institute of Oceanography and Fisheries, Egypt.
}

\begin{abstract}
$\mathrm{T}$ he present study was carried out to evaluate the effect of adding ascorbic acid to Tilapia fish diets on survival, growth, physiological parameters and total production. $O$. niloticus at average initial body weight $20.3^{+0.9} \mathrm{~g}$ and length $13.5^{+0.6} \mathrm{~cm}$, were stocked in concrete ponds at a rate of $5 \mathrm{fish} / \mathrm{m}^{3}$, and offered a diet of $5 \%$ of body weight, six days weekly, twice daily. The basal diet contained $30 \%$ crude protein divided into five tested diets. Ascorbic acid was added to the basal diet at different levels, 0 , 300, 600, 900 and $1200 \mathrm{mg} \mathrm{AA} / \mathrm{kg}$ diet.
\end{abstract}

The results show that tilapia growth performance indices (FBW, A.DG, SGR, GR and FCR) were increased with increasing ascorbic acid (AA) levels. Diet contained $900 \mathrm{mg} / \mathrm{kg}$ recorded the best value, compared to the control diet. The best biological indices (hepato., gonado and gastrosomatic indices were recorded from diet (4) compared to the control diet. Survival and production were increased with the increase of ascorbic acid level until $900 \mathrm{mg} / \mathrm{kg}$ diet which recorded the best results.

Similar results were obtained in blood properties (Erythrocyte, hematocrit and hemoglobin) as values showed the same pattern;, fish groups offered diet contained $900 \mathrm{mg} \mathrm{AA} / \mathrm{kg}$ had the best results comparing to the control diet; muscles, serum lipid values decreased with increasing A.A level. Protein content showed best values in fish fed A A up to $900 \mathrm{mg} / \mathrm{kg}$ diet.

The observation on fish growth and health showed that Ascorbic Acid can be used as a commercial compound to reduce production costs and to increase total final profit.

Key words : Oreochromis niloticus, ascorbic acid, growth parameters, physiological properties.

\section{INTRODUCTION}

Vitamins are organic nutrients which arc called accessory factors required in small quantities for biochemical functions (Idris \& Hasson ,2002). Metabolic reactions and normal growth in animals arise from functions of vitamins as cofactors for many growth enzymes in animal bodies that are indispensable nutrients required to maintain the physiological processes of 
different animals including fishes (Tolbert, 1979). Fish depend upon an exogenous sources of vit. C. as they cannot sunthesize it due to the absence of the enzymes. Agylonolflon L. gulonolactone oxidase (Ec1.1.3.8) (Wilson, 1973).

Because of the unstable nature of vit $\mathrm{C}$. , the use of non stable forms of ascorbic acid derivatives in aquatic feeds is necessary. vit. C. requirements for blue hybrid (Shiau \& Jan , 1992 ) and hybrid tilapia (Shiau \& Hsu , 2002 ) have been reported, L-Ascorbic acid (AA) is unstable and most of its activity in practical diets is lost during processing - storage. Shiau \& Hsu (1993) found that $75 \%$ from vit. C. amount was lost at ambient temperature .

The influence of vit. C. on fish health was studied by several researchers . Halver (1992) and Shiau \& Hsu (2007) cleared vit. C. role in fish health and tissue repair. Angrawal et al. (1978) showed the protective role of ascorbic acid in fish exposed to pesticide pollution and Navarre et al. (1989) reported that the diseases resistance and humoral antibodies production in fish can be offered different by levels of vit .C .

Vit. C. dietary levels influence on growth rate of tilapia fish was studied by Shiau \& Jan (1992), while Lee et al. (1998) reported that growth performance of Korean roach fish increases with increased vit. C. levels in diet to 1500 $\mathrm{mg} / \mathrm{kg}$ diet. Hung et al. (2007) observed that vit . C. can be used with minerals to obtain best results in fish health and growth.

The aim of this study was to evaluate the effect of adding vit. C. by various levels on $O$. niloticus growth, survival and physiological properties.

\section{MATERIAL AND METHODS}

\section{1) Experimental site and used fish:}

This study was carried out at El-Kanater fish research station in five concrete ponds with area of $8 \mathrm{~m}^{3}(4 \times 2 \times 1$ for each pond) filled with fresh water from Darawa irrigation canal . O. niloticus fish were obtained from El-Abbasa fish research station of average initial body weight $20.3^{+0.90} \mathrm{~g}$ and $13.5 \mathrm{~cm}$ length. They were stocked at rate $5.0 \mathrm{fish} / \mathrm{m}^{3}$ and fed with a diet containing 30 $\%$ crude protein and the rearing period was 90 days.

\section{2) Formulation of diets:}

Supplemented diets chemical composition and proximate analysis is presented in Table (1). Basal diets contained 30\% crude protein divided to five tested diets:

- Basal diet without adding vit. C. (control diet).

- diet 2 Basal diet contained $300 \mathrm{mg}$ vit. C. $/ \mathrm{kg}$ et .

- diet 3 Basal diet contained $600 \mathrm{mg}$ vit. C. $/ \mathrm{kg}$ et.

- diet 4 Basal diet contained $900 \mathrm{mg}$ vit. C. $/ \mathrm{kg}$ et

- diet 5 Basal diet contained $1200 \mathrm{mg}$ vit. C./kg et.

The tested diets were offered to O. niloticus as dry pellets $(3 \mathrm{~mm}$ diameter and $5 \mathrm{ml}$ length) 
Table (1) Feed intake, chemical composition, proximate analysis to O. niloticaus as affected by dietary supplemented vit. C.

\begin{tabular}{|c|c|c|c|c|c|c|c|}
\hline \multirow{3}{*}{ Ingredients } & \multicolumn{5}{|c|}{ Total weight $\%$} & \multirow{3}{*}{\multicolumn{2}{|c|}{ Proximat analys }} \\
\hline & Diet & Diet & Diet & Diet & Diet & & \\
\hline & 1 & 2 & 3 & 4 & 5 & & \\
\hline Cottonseed cake & 20.0 & 20.0 & 20.0 & 20.0 & 20.0 & crude protein $\%$ & 29.8 \\
\hline Soybean meal & 20.0 & 20.0 & 20.0 & 20.0 & 20.0 & crude fiber $\%$ & 6.9 \\
\hline Fish meal & 10.0 & 10.0 & 10.0 & 10.0 & 10.0 & Elher extract $\%$ & 8.9 \\
\hline Rice bran & 10.0 & 10.0 & 10.0 & 10.0 & 10.0 & ASH \% & 8.9 \\
\hline Wheat bran & 39.0 & 39.0 & 39.0 & 39.0 & 39.0 & Nitrogen free extract $\%$ & 10.5 \\
\hline Oil & 1.0 & 1.0 & 1.0 & 1.0 & 1.0 & $\begin{array}{c}\text { Gross-energy } \mathrm{k} \\
\mathrm{Cal} / \mathrm{kg} \text { diet }\end{array}$ & 4250 \\
\hline Vitamin C mg / $100 \mathrm{~g}$ diet & - & 300 & 600 & 900 & 1200 & & \\
\hline
\end{tabular}

\section{3) Blood analysis and sexual maturity:}

The blood samples (15 fish examined from each pond) were taken over heparinized vials by severing the caudal peduncle of the fish (Dabroweska el al., 1989) The erythrocytes count was determined using a double hemocytometer (Wintrobe 1934). The hematocrit value was measured by drawing blood directly from fish into heparinized hemopipette, then centrifuged at $3000 \mathrm{rpm}$ (Hesser, 1960). Hemoglobin content was estimated by Van Kampen \& Zijfstra (1961). Serum glucose was measured by using Bohringer Mannheim kits as described by Tinder (1969) and serum lipid by Zoliner \& Kirsch (1962) methods. Protein in serum and muscles was measured according to Gornall, et al., (1949), Glycogen in muscles was determined by using anthrone reagent (Handel, 1965), total lipid in muscles was extracted with mixture of chloroform and methanol (2:1) and determined using Bligh \& Dyer (1959) method.

\section{4) Growth rate and feed utilization:}

During fish rearing period every 15 days fish from each pond were measured, (Length - weight), and physico-chemical parameters were measured to determine $\mathrm{pH}$. dissolved oxygen, total alkalinity and water temperature to study the water quality for the reared fish. At the end of study: growth performance of reared fish were measured according to the following :

TWG $=$ final body weight - initial body weight.

$\mathrm{SGR}=$ Ln final weight - Ln initial weight / period $\mathrm{x} 100$

GR = final weight - initial weight $/$ initial weight $\times 100$

TFC. $=($ Average weight $\mathrm{x}$ fish number $\mathrm{x} 3 / 100$

F.C.R $=$ Total food consumption / weight gain $\mathrm{g} x$ fish number. 


\section{5) Statistical analysis :}

The experimental results were statistically analyzed using $\mathrm{T}$ test and $\mathrm{F}$ test of significance according to Snedecor \& Cochran (1967) .

\section{RESULTS}

Table (2) shows fish growth performance, final body weight (FBW), Average daily gain (AD.G), specific growth rate (SGR), Growth ratio ('GR), and feed conversion ratio (FCR) as affected by adding vit. C. (Ascorbic acid) at different levels $(0,300,600,900$, and $1200 \mathrm{~g} / \mathrm{kg}$ diet $)$.

Table (2) shows that maximum differences were observed in growth performance with significantly higher values (97.2 0.88 ، 1.23 and 380.0 respect.) were obtained from fish offered diet (4) that contained vit. C. at level $900 \mathrm{mg} / \mathrm{kg}$ diet, compared to fish group fed control diet which recorded the lowest values (70.5 ، 0.55 ، 0.91 and $244.8 \%$ respect.). Nutrient , efficiency as shown from table (2), revealed that $O$. niloticus nutrient ratio (Protein effeciency ratio: values increased with increasing Ascorbic acid levels until $900 \mathrm{mg} / \mathrm{kg}$ diet, the highest value (1.89) was recorded from fish fed diet (4) containing vit. C. at level $900 \mathrm{mg}$ compared with control diet which recorded lowest value (1.3).

Feed conversion ratio showed the same pattern. Differences were significant while the lowest and be value was recorded from fish groups offered diet (4), at A.A. level 900mg compared to diet (1) without adding vit. C .

Table (2) Average growth performance, P.E.R and F.C.R. for O. niloticaus as affected by adding vit. $\mathrm{C}$ with different levels .

\begin{tabular}{||l|c|c|c|c|c|c||}
\hline \multicolumn{1}{|c|}{ Treatments } & $\mathbf{T}_{\mathbf{1}}$ & $\mathbf{T}_{\mathbf{2}}$ & $\mathbf{T}_{\mathbf{3}}$ & $\mathbf{T}_{\mathbf{4}}$ & $\mathbf{T}_{\mathbf{5}}$ & $\mathbf{M S E}^{+}$ \\
Vit .C. concentration mg/kg diet Items & $\mathbf{0 . 0}$ & $\mathbf{3 0 0}$ & $\mathbf{6 0 0}$ & $\mathbf{9 0 0}$ & $\mathbf{1 2 0 0}$ & \\
\hline - aver. initial body weight (g) & 20.3 & 20.3 & 20.3 & 20.3 & 20.3 & 0.90 \\
\hline - aver. final body weight (g) & $705^{\mathrm{d}}$ & $75.4^{\mathrm{c}}$ & $90.7^{\mathrm{ab}}$ & $97.2^{\mathrm{a}}$ & $92.3^{\mathrm{b}}$ & 3.5 \\
\hline - aver. daily Iain (g/fish/day) & $0.55^{\mathrm{d}}$ & $0.61^{\mathrm{c}}$ & $0.78^{\mathrm{ab}}$ & $0.85^{\mathrm{a}}$ & $0.80^{\mathrm{b}}$ & 0.01 \\
\hline - S.G.R\% & $0.91^{\mathrm{d}}$ & $0.97^{\mathrm{c}}$ & $0.16 \mathrm{a}^{\mathrm{b}}$ & $1.23^{\mathrm{a}}$ & $1.17^{\mathrm{b}}$ & 0.07 \\
\hline - Growth rate\% & $244.8^{\mathrm{d}}$ & $271.4^{\mathrm{c}}$ & $346.7^{\mathrm{ab}}$ & $380.6^{\mathrm{a}}$ & $354^{\mathrm{b}}$ & 16.5 \\
\hline - P.E.R\% & $1.3^{\mathrm{d}}$ & $1.59^{\mathrm{c}}$ & $1.66^{\mathrm{ab}}$ & $1.89^{\mathrm{a}}$ & $1.86^{\mathrm{b}}$ & \\
\hline - Feed consumed. & 150.5 & 153.4 & 1.37 & 142.0 & 138.3 & 0.11 \\
\hline - F.C.R\% & $2.44^{\mathrm{d}}$ & $2.79^{\mathrm{c}}$ & 1.95 & $1.85^{\mathrm{a}}$ & 1.92 & 0.06 \\
\hline
\end{tabular}

a,b,c. etc mean in the same row with different superscript are different $(\mathrm{p}<\mathrm{O} .05)$.

$\mathrm{MSE}=$ mean standard error calculated from residual mean square in the analysis of variance.

Data given in Table (3) Show that $O$. niloticus as affected by adding A.A. at different levels had biological indices (hepato - gonado and gastro somatic indices at a significant differences $(\mathrm{p}<0.05)$, Maximum values (5.9، 10.85 and 12.8 respect.), for the male and (5.9 6.28 and 12.8 respect.) for female were obtained from diet (4) with (900) $\mathrm{mg} / \mathrm{Kg}$ diet. while the lowest values (4.45, 7.9 and 11.5 respect.) for males and (4.45 ، 4.92 and 11.51 respect.) for females were recorded from fish groups fed the control diet. 
Table (3) shows the survival and total production which revealed the same better value. Differences were significantly higher (100\%) in fish groups offered diet (4), with contrast to the control fish which recorded the lowest survival value (90\%). Table (3) shows the total production $(\mathrm{Kg} / \mathrm{pond})$ and the net production $\left(\mathrm{kg} / \mathrm{m}^{3}\right)$ and the net production $\mathrm{kg} /$ fedd. for $O$. niloticus as affected by adding AA . Maximum values (3.08 ، 0.285 and 1190.0 respect.) were obtained from fish fed diet contained $900 \mathrm{mg}$ AA/kg diet, while fish groups offered the control diet recorded the lowest values $(1.8 \cdot 0.125$ and 5250.00 respect .)

Table (3) Biological indices, survival performance and net return of O. niloticaus as affected by adding vit. $\mathrm{C}$.

\begin{tabular}{|c|c|c|c|c|c|c|}
\hline $\begin{array}{c}\text { Treatments } \\
\text { Vit .C. concentration } \mathrm{mg} / \mathrm{kg} \text { diet Items }\end{array}$ & $\begin{array}{l}\mathbf{T}_{1} \\
\mathbf{0 . 0}\end{array}$ & $\begin{array}{c}\mathbf{T}_{2} \\
300\end{array}$ & $\begin{array}{c}T_{3} \\
600 \\
\end{array}$ & $\begin{array}{c}T_{4} \\
900\end{array}$ & $\begin{array}{c}\mathbf{T}_{5} \\
\mathbf{1 2 0 0}\end{array}$ & $\mathrm{MSE}^{+}$ \\
\hline $\begin{array}{l}\text { Biological indices: } \\
\text { - hepato soma index } \\
\text { - gastro somatic index } \\
\text { - Goanado somatic index: } \\
\text { 1) : Male fish } \\
\text { 2) : female fish. }\end{array}$ & $\begin{array}{c}4.45^{\mathrm{d}} \\
11.51^{\mathrm{d}} \\
7.9^{\mathrm{d}} \\
4.92^{\mathrm{d}} \\
\end{array}$ & $\begin{array}{l}4.9^{\mathrm{c}} \\
12.53^{\mathrm{c}} \\
8.52^{\mathrm{c}} \\
5.90^{\mathrm{c}} \\
\end{array}$ & $\begin{array}{l}5.88^{\mathrm{ab}} \\
12.7^{\mathrm{ab}} \\
987^{\mathrm{ab}} \\
6.11\end{array}$ & $\begin{array}{c}5.9^{\mathrm{a}} \\
12.8^{\mathrm{a}} \\
\\
10.95^{\mathrm{a}} \\
6.28^{\mathrm{a}} \\
\end{array}$ & $\begin{array}{c}5.5 \\
12.66 \\
\\
9.55^{\mathrm{b}} \\
16.10^{\mathrm{b}} \\
\end{array}$ & $\begin{array}{c}0.9 \\
1.02 \\
\\
1.03 \\
1.90 \\
\end{array}$ \\
\hline $\begin{array}{l}\text { Survival performance: } \\
\text { - fish number at starting. } \\
\text { - fish number at harvesting. } \\
\text { - losses number. } \\
\text { - survival rate. }\end{array}$ & $\begin{array}{l}40.0 \\
36.0 \\
4.0^{\mathrm{d}} \\
90^{\mathrm{d}}\end{array}$ & $\begin{array}{l}40.0 \\
37.0 \\
3.0 \\
92.5^{\mathrm{c}}\end{array}$ & $\begin{array}{l}40.0 \\
38.0 \\
2.0 \\
195^{\mathrm{ab}}\end{array}$ & $\begin{array}{c}40.0 \\
40.0 \\
0.0 \\
100^{\mathrm{a}}\end{array}$ & $\begin{array}{c}40.0 \\
38.0 \\
2.0 \\
95\end{array}$ & \\
\hline $\begin{array}{l}\text { Total production I pond: } \\
\text { - net production }(\mathrm{kg}) / \mathrm{pond} \\
\text { - net production }(\mathrm{kg}) / \mathrm{m} 3 \\
\text { - net production. }(\mathrm{kg}) 1 \mathrm{fed} \text {. }\end{array}$ & $\begin{array}{l}1.80^{\mathrm{d}} \\
1.00^{\mathrm{d}} \\
0.125^{\mathrm{d}} \\
525.0^{\mathrm{d}}\end{array}$ & $\begin{array}{l}2.042^{\mathrm{c}} \\
1.23^{\mathrm{c}} \\
0.154^{\mathrm{c}} \\
645.0^{\mathrm{c}}\end{array}$ & $\begin{array}{l}2.865^{\mathrm{ab}} \\
2.065^{\mathrm{ab}} \\
0.258^{\mathrm{ab}} \\
1084^{\mathrm{ab}}\end{array}$ & $\begin{array}{l}3.080^{\mathrm{a}} \\
2.268^{\mathrm{a}} \\
0.283^{\mathrm{a}} \\
1190^{\mathrm{a}}\end{array}$ & $\begin{array}{c}2.73^{\mathrm{b}} \\
1.9^{\mathrm{b}} \\
0.32^{\mathrm{b}} \\
982.2^{\mathrm{b}}\end{array}$ & \\
\hline
\end{tabular}

a,b,c. etc mean in the same row with different superscript are different $(\mathrm{p}<0.05)$.

$\mathrm{MSE}=$ mean standard error calculated from residual mean square in the analysis of variance.

Table (4) illustrates blood parameters (Erythrocyte count, (million) $/ \mathrm{mm}^{3}$ Hematocrit values and Hemoglobin content for $O$. niloticaus as affected by adding vit. C. at five levels. Differences were obtained in blood parameters with significantly higher values, (2.59 ، 34.70 and 13.57 respect.) from fish groups offered diet contained $900 \mathrm{~g} / \mathrm{kg}$ diet . Compared to fish groups fed the control diet which recorded the lowest values (1.85 ، 31.58 and 8.57 respect.).

Data in Table (4) show that muscles composition (total protein $\mathrm{g} / \mathrm{l00g}$. fresh tissues. Glycogen $\mathrm{mg} / 100 \mathrm{~g}$ fresh tissues and total lipid $\mathrm{g} / 100 \mathrm{~g}$ fresh tissues, had a significant differences $(p<0.05)$ Differences obtained in lipid content with significant higher values(7.4) shown in fish offered control diet without AA, while fish group fed the diet contained 900mg AA/Kg diet had the best value (5.95). 
In order to clear the differences in protein and glycogen results, maximum values (18.2 and .1.18) were obtained from fish fed diet (4) compared to fish offered control diet with the lowest value $(15.61,1.35$ respect.).

From Table (4), serum analysis (glucose $\mathrm{mg} / 100 \mathrm{ml}$ serum, lipid g /100 $\mathrm{ml}$ serum and protein $\mathrm{g} / 100 \mathrm{ml}$ serum .The same pattern of highest value (5.55) in lipid content was recorded from fish fed the control diet, in contrast to diet (4) which recorded the lowest and better valeu . Differences were shown in protein and glucose with significantly higher values (14.7and 60.33) from fish offered diet contained vit . C . At $900 \mathrm{mg} / \mathrm{kg}$ diet, while fish fed diet without add. vit . C. had the lowest value (11.3 and 54.5 respect. ).

Table (4) Blood parameters . serum analysis and biochemical composition of muscles in $O$. niloticaus as affected by adding dietary vit. C .

\begin{tabular}{|c|c|c|c|c|c|c|}
\hline $\begin{array}{c}\text { Treatments } \\
\text { Vit .C. concentration } \mathrm{mg} / \mathrm{kg} \text { diet Items }\end{array}$ & $\begin{array}{l}\mathbf{T}_{1} \\
\mathbf{0 . 0}\end{array}$ & $\begin{array}{c}\mathbf{T}_{2} \\
\mathbf{3 0 0}\end{array}$ & $\begin{array}{c}\mathbf{T}_{3} \\
600\end{array}$ & $\begin{array}{c}\mathbf{T}_{4} \\
\mathbf{9 0 0}\end{array}$ & $\begin{array}{c}T_{5} \\
1200\end{array}$ & MSE $^{+}$ \\
\hline $\begin{array}{l}\text { Blood parameters: } \\
\text { - Erythrocyte count }\left(\text { milion } / \mathrm{mm}^{3}\right) \text {. } \\
\text { - Hematocrit value } \% . \\
\text { - Hemoglobin content }(\mathrm{g} / 100) \\
\text { Mnscle compositions } \\
\text { - Protein } \mathrm{g} / 100 \mathrm{~g} \text { fresh tissue } \\
\quad \text {-Glycogen }(\mathrm{mg} / 100 \mathrm{~g} \text { fresh tissue). } \\
\text { - Lipid }(\mathrm{g} / 100 \mathrm{~g} \text { fresh tissue). }\end{array}$ & $\begin{array}{c}1.86^{\mathrm{d}} \\
31.75^{\mathrm{d}} \\
8.56^{\mathrm{d}} \\
\\
15.61^{\mathrm{d}} \\
11.35^{\mathrm{d}} \\
7.41^{\mathrm{d}} \\
\end{array}$ & $\begin{array}{c}1.85^{\mathrm{c}} \\
34.06^{\mathrm{c}} \\
8.95 \mathrm{c} \\
\\
15.95 \mathrm{c} \\
1.56 \mathrm{c} \\
6.31^{\mathrm{c}} \\
\end{array}$ & $\begin{array}{c}2.01^{\mathrm{ab}} \\
39.55^{\mathrm{ab}} \\
12.3^{\mathrm{ab}} \\
16.59^{\mathrm{ab}} \\
1.71^{\mathrm{ab}} \\
6.1 \\
\end{array}$ & $\begin{array}{c}2.59^{\mathrm{a}} \\
43.78^{\mathrm{a}} \\
13.57^{\mathrm{a}} \\
\\
18.2^{\mathrm{a}} \\
1.18 \\
5.95^{\mathrm{a}} \\
\end{array}$ & $\begin{array}{c}2.95^{\mathrm{b}} \\
42.9^{\mathrm{b}} \\
12.7^{\mathrm{b}} \\
17.3^{\mathrm{b}} \\
1.69^{\mathrm{b}} \\
6.0^{\mathrm{b}} \\
\end{array}$ & $\begin{array}{c}0.156 \\
2.55 \\
1.7 \\
\\
1.9 \\
0.02 \\
0.90 \\
\end{array}$ \\
\hline $\begin{array}{l}\text { Serum analysis } \\
\text { - Glucose }(\mathrm{mg} / 100 \mathrm{ml} \text { serum. } \\
\text { - lipid }(\mathrm{g}) / 100 \mathrm{ml} \text { serum. } \\
\text { - proteien }(\mathrm{g}) / 100 \mathrm{ml} \text { serum. }\end{array}$ & $\begin{array}{l}54.5^{\mathrm{d}} \\
5.55^{\mathrm{d}} \\
11.3^{\mathrm{d}}\end{array}$ & $\begin{array}{l}70.33^{\mathrm{c}} \\
4.84^{\mathrm{c}} \\
12.9 \mathrm{c}\end{array}$ & $\begin{array}{l}55.73^{\mathrm{ab}} \\
4.5^{\mathrm{ab}} \\
13.55^{\mathrm{ab}}\end{array}$ & $\begin{array}{c}60.33^{\mathrm{a}} \\
4.00^{\mathrm{a}} \\
17.7\end{array}$ & $\begin{array}{l}58.82^{\mathrm{b}} \\
4.45^{\mathrm{b}} \\
14.5^{\mathrm{b}}\end{array}$ & $\begin{array}{c}5.33 \\
0.08 \\
1.9\end{array}$ \\
\hline
\end{tabular}

a,b,c. etc mean in the same row with different superscript are different $(\mathrm{p}<0.05)$.

$\mathrm{MSE}=$ mean standard error calculated from residual mean square in the analysis of variance.

\section{DISCUSSION}

O. niloticaus as affected by adding dietary supplemented Ascorbic acid (AA), growth performance increas with the increase in (AA) level until 900 $\mathrm{mg} / \mathrm{kg}$ diet. This result is in agreement with the observation of Sweilum (2005), who found that growth performance of such fish increased with increasing vit. C. level until $750 \mathrm{mg} / \mathrm{kg}$ diet, also with previous studies of Mohajon \& Agrawal (1980) on the nutritional requirement of Ascorbic Acid for Indian major carp that showed that growth rate was increased by increasing the levels of (A A) in the diets up to $600.0 \mathrm{mg} / \mathrm{kg}$ diet. Similar observation was obtained by Shiau \& Jan (1992), who mentioned that vit. C. required for maximum growth in Tilapia fish is $790 \mathrm{mg} / \mathrm{kg}$ diet. While Lee et al. (1998) reported that the weight gain, feed conversion factor showed the highest value for Korean-rock fish with feeding dietary ascorbic acid level at $1500 \mathrm{mg} / \mathrm{kg}$ diet.

The requirement levels of dietary (AA) for growing fish were illustrated from different fish as following: $100 \mathrm{mg} / \mathrm{kg}$ diet for rainbow trout ( Hilton et al., 1978 ), $50 \mathrm{mg} / \mathrm{kg}$ diet for blue Tilapia (Stickney et al.,1990), $60 \mathrm{mg} / \mathrm{kg}$ for 
channel cat fish (El- Naggar \& Lovel, 1991) and $400 \mathrm{mg} / \mathrm{kg}$ diet EI-Hammady et al. (2002).

Data of survival rate had better results shown in fish offered diet contained $900 \mathrm{mg} / \mathrm{kg}$, diet, in accordance with that postulated by EIShandaweily (1999) and sweilum (2005) in Tilapia fish. Total production recorded better values for fish fed diet contained $900 \mathrm{mg} / \mathrm{kg}$ diet. This agrees with the observation recorded by El-Hammady et al. (2002), that ascorbic acid at level of $600 \mathrm{mg} / \mathrm{kg}$ diet, recorded the highest value in fish production for $O$. niloticaus.

The present results of Red-blood cells count, hematocrit and hemoglobin had the maximum values in fish fed diet contained $900 \mathrm{mg} / \mathrm{kg}$ diet with contrast to the control diet. Similar observation was shown by Shiau \& Jan (1992) which revealed that macrocytic anemia has been shown in Tilapia sp., when fed diet deficient of (AA), EL Hammady \& EL said (2002) cited that the best hematocril and hemoglobin of Tilapia sp. were recorded with increasing dietary (A.A) level up to $600 \mathrm{mg} / \mathrm{kg}$ diet .

Serum glucose and lipid were decreased with increasing (A.A) levels up to $900 \mathrm{mg} / \mathrm{kg}$ diet. while serum protein values were increased directly with the increasing in vitamin C levels. Similar results were observed by Kibatchi (1967) and Sweilum (2005) who reported that adding vit .C. (optimum), level to fish showed the conversion of unsaturated fatty acid to lipid.

The present results show that biochemical composition of fish muscles were also affected by adding ascorbic acid in the diets, where total protein and glycogen were increased with the increasing of (AA) requirement, while total lipids decreased with the increase in vit. C. level until $900 \mathrm{mg} / \mathrm{kg}$ diet. Simitar record were observed by Mahanjan et al. (1980). when fed carp fishes on diets contained $650-750 \mathrm{mg} / \mathrm{kg}$ diet of (AA).

\section{CONCLUSION}

At the end of the present research, the observation enhancing fish growth and health, reported that Ascorbic acid can be used as a commercial product to reduce the production costs and to increase the final net production and profit in aquaculture.

\section{REFERENCES}

Agrawal, N. K.; Juneja, C. J. and Mahajan, C . L . (1978) Protective role of ascorbic acid in fish exposed to organic chlorine pollution Tox., 11: 369-375.

APHA ; American public Health Association (1992). standard Methods for the examination of water and waste water, $12^{\text {th }}$ edition, Inc. New York, $769 \mathrm{pp}$. 
Bligh, E . G and Dyer, W . T. ( 1959) . A rapid methods of total lipid extraction and purification: Canadian Journal of Bio. and Phy., 37: 911- 917.

Dabrowska, H ; Burgdrof, K. and Gunther, k. (1989). Interaction between dietary protein and magnesium level In Tilapia (Oreochromis niloticus) Aquacul., 76:277-291 .

EI-Hammady, A. K. and El-Said S. M. (2002). Influence of dietary supplementation of vitamin C. to practical diets on growth and some blood parameters of hybrid Tilapia. Egypt. Acad. Soc. Environ. Development 2:29-50.

EI-Naggar, G. O. and Lovell, R. T. (1991).L.Ascorbyle-2- monophophate has equal antiascorbic activity as L-ascorbic acid but L. ascorbyle 2-sulphate is interion to L-ascorbic acid for channel catfish, J. of Nutr., 121:16221626.

El-Shandaweily, M. Z. (1999). Effect of fertilization or feeding system on performance of Nile Tilapia (Oreochiromis niloticus) and Grey Mullet (Mugil cephalus) in polyculture earthen ponds, Cairo Unive., (ElFayom Branch) Egypt.

Fish Farming International, F.F.I. (1984). vitamin C has high place in feeds for farm fish FF, pp. 11-18.

Gornall, A. C. Bardwill, G. J. and David, M . M. (1949). Determination of serum protein by Bruit reagent. J. Biol and Chem., 177 : 751 pp.

Halver , J . E. ( 1972) . The role of ascorbic acid in fish disease and tissue repair, Bull. Jap. Soc. And fish, 38:79-92.

Handel, E.V. (1965). Estimation of glycogen in small amount of tissue Analyt. Bioch., J. 8: 165-265.

Hesser, E.F. (1960). Methods for routine fish hematology. Progressive fish culturist, 22: 164-1 71 .

Hiltoon, J. W.; Cho, C.Y. and slinger, S. I. (1978). Effect of graded level of supplemental ascorbic acid in practical diets fed to Rainbow trout (Salmo gairdneri ), J. of the fish. Res. Board of canada 35:341- 436.

Hung, S.w.; Tu , C. Y. and Wang, W. S. (2007). Effect of adding singular or combined anti-oxidative vitamins and or minerals to diets on the 
immune system of Tilapia (Oreochromis hybrid) perepheral blood monocytc- derived, anterior kidney-derived, and spleen macrophages, vet. Immun. \& Immunopath. $115: 87$ - 99 .

Kibatchi, A. E. (1967). Ascorbic acid in steroidgenesis Nature 215:385-1386.

Idris, A. and Hassan, A. A. (2002). Review of medical biochemistry. Biochemistry Department Benha, faculty of Medicine, Zagazig univEgypt.

Lee, K . J.; Kim, K.W and Bai, S. C. (1992). Effect of different dietary levels of L-ascorbic acid on growth and tissue vitamin $\mathrm{C}$ concentration in Juvenile Korean rock fish (Sebasles schlegeli) Aquacul. Research 29: 237-244.

Mahajan, C. L., and Agrawal, N. K.,(1980). Nutritional requirement of ascorbic acid by Indian major carp. (Eirrhia mrigala) during early growth. Aquacul., 19: 37 - 48.

Navarre, O., Halver, J. E. (1989). Desease resistance and humoral antibody production in rainbow trout fed high levels of vit., Aquacul. 79:207-221.

Shiau, S.Y., and Jan, F.L., (1992). Dietary ascorbic acid requirement of Juvenile Tilapia (Oreochromis niloticus x. O. aurea,) Nippon Suisan Gakkaishi, 58:671-675.

Shiau, S.Y., Hsu, C.Y., (1993). Stability of ascorbic acid in shrimp feed during analysis, Nippon, Suisan Gakkaishi, 59:1535-1537.

Shiau, S.Y., \& Hsu. C.Y., (2002). Vitamin E sparing effect by dietary vitamin C in Juvenile hyprid Tilapia (Oreochromis niloticus x O. aurea.,) Aquacul. $210.335-342$.

Snedecor, G. W and Cochran W.G (1967) Statistical mehods . Lowa state, Univ. press. Ames. USA. Pp. $327-329$.

Stickney, R.R.; McGeachin, R. B. Lewis, D.H. and Worts, W. (990). (Response) of Tilapia aurea to dietary vitamin C, J. of world Mari. culture society, 15: 179-185.

Sweilum, M.A., (2005): Effect of different Dietary levels of L-Ascorbic Acid (vitamin C) on growth parameters and some physiological properties of 
Sarotherodon Galilaeus, J., Egyptian Exp. Biol., (Zool.) 1:131-136.

Trinder, R (1969): Determination of glucose in blood/serum or plasma by enzymatic colorimetric methods. Annual clinical. Bioch. , 6:24.pp.

Tolbert, B.M.,(1979). Ascorbic acid metabolism and physiological function, Int. J. Vit. Nutr, Res. 19:127-142.

Van-Kampen, E.T. and Zijfstra, W.G. (1961). Recommendation for hemoglobino metry in human blood chemistry Actual 6:338 pp.

Wilson, R.P., Bowser, R.P., Peo, W.E., (1973). Absence of ascorbic acid synthesis in channel catfish (Ictalurus punctuatus) and blue cat fish (Ictalurus frucatus), Comp. Bioche. Physiol. B.46:635-638.

Wintrope, M. M. (1934). Variation in the size and hemoglobin content of erythrocytes in blood of various vertebrates, Folia Hemato., 51:32- 49.

Zoliner, N., and Kirsch, K., (1962). Uber diet quantitative Bestiming van Lipoiden (al Len be . kannten Plasmalipoiden) gemiensa,en sulfophoso vanillin- rektion zges Exp. Med., 135: 545-561. 